Article

\title{
Sorbicillinoid-Based Metabolites from a Sponge-Derived Fungus Trichoderma saturnisporum
}

\author{
Junjun Meng ${ }^{1,2,+}$, Wei Cheng ${ }^{1,+}{ }^{+}$Hajar Heydari ${ }^{3,+}{ }^{+}$Bin Wang ${ }^{2}$, Kui Zhu ${ }^{4}{ }^{(D)}$, \\ Belma Konuklugil ${ }^{3}$ and Wenhan Lin ${ }^{1, * \text { (D) }}$ \\ 1 State Key Laboratory of Natural and Biomimetic Drugs, Peking University, Beijing 100191, China; \\ 13683042952@163.com (J.M.); chengwei@bjmu.edu.cn (W.C.) \\ 2 Food and Medicine College, Zhejiang Ocean University, Zhoushan 316022, China; wangbin@zjou.edu.cn \\ 3 Department of Pharmacoguosy, Faculty of Pharmacy, Ankara University, Tandogan, Ankara 06100, Turkiye; \\ hajar.heydari@yahoo.com (H.H.); belma.konuklugil@gmail.com (B.K.) \\ 4 College of Veterinary Medicine, China Agricultural University, Beijing 100193, China; zhukcau@gmail.com \\ * Correspondence: whlin@bjmu.edu.cn; Tel.: +86-10-82806188 \\ + These authors contributed equal to this work.
}

Received: 8 June 2018; Accepted: 27 June 2018; Published: 4 July 2018

check for updates

\begin{abstract}
Antibacterial activity assessment and high performance liquid chromatography associated with nuclear magnetic resonance (HPLC/NMR) data revealed that the EtOAc extract of the fermented endophytic fungus Trichoderma saturnisporum DI-IA, obtained from the marine sponge Dictyonella incisa, contained conjugated olefinic metabolites with antibacterial activity. Chemical examination of the fungal strain resulted in the isolation of eight new sorbicillinoid-based compounds, namely saturnispols A-H (1-8). Their structures were determined on the basis of extensive spectroscopic analysis, including the experimental and calculated electronic circular dichroism (ECD) data for the configurational assignments. Saturnispol F exerted significant inhibition against a panel of bacteria strains including vancomycin-resistant enterococci (VRE) with a minimum inhibitory concentrations (MIC) ranging from 1.63 to $12.9 \mu \mathrm{g} / \mathrm{mL}$, while saturnispol $\mathrm{H}$ showed selective effects against VRE and B. subtilis.
\end{abstract}

Keywords: marine fungus; Trichoderma saturnisporum; saturnispols A-H; structural elucidation; antibacterial effects

\section{Introduction}

Sorbicillinoids are a class of fungal metabolites with a cyclic hexaketide nucleus, which contains a typical or modified sorbyl sidechain [1,2]. Since the isolation of the first member of the sorbicillinoid family 60 years ago (sorbicillin, from the fungus Penicillium notatum) [3], approximately 100 sorbicillin derivatives have been reported from several strains of fungi obtained from diverse environmental sources. Based on their structural modification and condensation, they are classified into monomers [4], bisorbicillinoids [5-8], trisorbicillinoids [9,10], and hybrid sorbicillinoids [11-13]. These typical natural products possess a range of bioactivities, including cytotoxic [14], antibiotic [15], antiviral [16], antioxidant [17], and lipid-lowering properties [18]. However, few studies have been reported that investigate the structure-activity relationship. Although most sorbicillinoids have originated from terrestrial fungi, marine-derived fungi have proved to be a promising source of derivatives. It is noted that sorbicillinoid-bearing marine fungi are distributed widely, from shallow water to deep sea environments. Among the marine-derived analogues, marine sponge-associated fungi are recognized to produce diverse sorbicillinoid derivatives with unique scaffolds. Sorbifuranones A-C from the sponge-derived fungus Penicillium chrysogenum are a novel class of intriguing sorbicillinol-derived 
metabolites [19]. JBIR-59, a dimer of sorbicillinol that lacks a sorbyl sidechain, has antioxidant effects and is produced by the sponge-derived fungus P. citrinum [17], while a group of novel sorbicillinoid polyketide derivatives were isolated from the Caribbean sponge Agelas dispar-associated fungus Trichoderma sp. [20]. Sorbicillinoid alkaloids were first found from a sponge-derived P. chrysogenum strain [16], and vertinoid polyketides with unique scaffolds were isolated from the sponge-associated fungus T. longibrachiatum. These findings demonstrate that sponge-associated fungi are a rich source of structurally unique sorbifuranones.

Vancomycin-resistant enterococci (VRE) have emerged as important hospital-acquired pathogens in immunosuppressed patients and are increasing steadily in occurrence. Antimicrobial therapy is problematic for all VRE, posing serious risks to the health of current and future patients. It is urgent to discover new natural antibiotics to overcome these drug-resistant pathogens. In the course of our search for antibacterial natural products derived from sponge-associated fungi, the marine fungus Trichoderma saturnisporum, which was isolated from the sponge of Dictyonella incise, showed a diverse chemical profile in its HPLC fingerprint and exerted antibacterial effects. This fungal species has rarely been chemically examined, with only one publication reporting peptaibols, namely paracelsins A-E [21]. Several Trichoderma species from terrestrial ecosystems have been registered as biocontrol agents to control fungal plant diseases [22,23]. The fungus T. saturnisporum is an unexploited species for the biocontrol of fungal diseases of plants, and it is a potential antagonist against important plant pathogens [22]. However, the chemical and biological properties of the marine-derived T. saturnisporum are unexplored and rarely described. In the present work, we describe the structural elucidation of eight new sorbicillinoid-based derivatives (Figure 1) from the sponge Dictyonella incisa-associated fungal strain T. saturnisporum and their antibacterial effects.

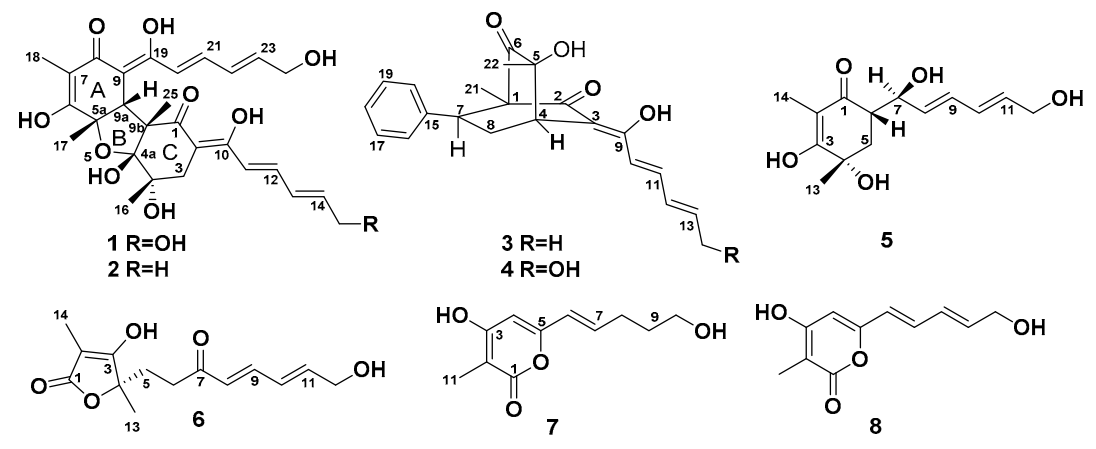

Figure 1. Structures of saturnispols A-H (1-8).

\section{Results}

The HPLC chromatograph in association with the ${ }^{1} \mathrm{H}$ NMR and electrospray ionization mass spectrometry (ESI-MS) data revealed that the ethyl acetate (EtOAc) extract of the rice fermentation of the fungus T. saturnisporum featured a profile of conjugated olefinic metabolites. The EtOAc extract inhibited Staphylococcus aureus ATCC 29213 with an MIC < $128 \mu \mathrm{g} / \mathrm{mL}$. Chromatographic separation of the EtOAc extract led to the isolation of eight new sorbicillinoid-related derivatives (Figure 1).

Saturnispol A (1) was obtained as a red oil. Its molecular formula was determined to be $\mathrm{C}_{28} \mathrm{H}_{34} \mathrm{O}_{10}$ on the basis of the high resolution electrospray ionization mass spectroscopy (HRESIMS) $\left(m / z 529.2069[\mathrm{M}-\mathrm{H}]^{-}\right.$, calcd for $\left.\mathrm{C}_{28} \mathrm{H}_{33} \mathrm{O}_{10}, 529.2074\right)$ and $\mathrm{NMR}$ data, requiring 12 degrees of unsaturation. The infrared radiation (IR) absorptions suggested the presence of hydroxy $\left(3380 \mathrm{~cm}^{-1}\right)$, carbonyl $\left(1738 \mathrm{~cm}^{-1}\right)$, and olefinic $\left(1614 \mathrm{~cm}^{-1}\right)$ groups. The ${ }^{13} \mathrm{C}$ NMR and distortionless enhancement by polarization transfer (DEPT) spectra exhibited a total of 28 carbon resonances, and they were classified into four methyls, three methylenes, nine methines, and 12 quaternary carbons. The connectivity of protons with their associated carbons was assigned by the heteronuclear single quantum coherence (HSQC) spectrum. The proton-proton correlation spectroscopy $\left({ }^{1} \mathrm{H}-{ }^{1} \mathrm{H}\right.$ COSY) correlations established a side chain for a hydroxylated pentadiene from $\mathrm{H}-20\left(\delta_{\mathrm{H}} 6.62, \mathrm{~d}\right.$, 
$J=15.2 \mathrm{~Hz})$ to $\mathrm{H}_{2}-24\left(\delta_{\mathrm{H}} 4.22, \mathrm{~d}, J=5.2 \mathrm{~Hz}\right)$. Inspection of the heteronuclear multiple bond correlation (HMBC) data, such as from $\mathrm{H}_{3}-17\left(\delta_{\mathrm{H}} 1.45, \mathrm{~s}\right)$ to C-6 $\left(\delta_{\mathrm{C}} 168.3\right), \mathrm{C}-5 \mathrm{a}\left(\delta_{\mathrm{C}} 79.2\right)$, and C-9a $\left(\delta_{\mathrm{C}} 53.7\right), \mathrm{H}_{3}-18$ $\left(\delta_{\mathrm{H}} 1.43, \mathrm{~s}\right)$ to $\mathrm{C}-6, \mathrm{C}-7\left(\delta_{\mathrm{C}} 109.3\right)$, and C-8 $\left(\delta_{\mathrm{C}} 191.9\right)$, as well as the correlations from H-9a $\left(\delta_{\mathrm{H}} 3.67\right.$, s) to C-8, C-9 $\left(\delta_{\mathrm{C}} 101.7\right), \mathrm{C}-6$, and C-5a, resulted in the presence of a cyclohexenone ring, in which Me-17 and Me- 18 were positioned at C-5a and C-7, respectively. Additional HMBC correlations from $\mathrm{H}-20$ to $\mathrm{C}-9$ and $\mathrm{C}-19\left(\delta_{\mathrm{C}} 166.5\right)$ deduced the location of a dihydroxylated hexadiene at C-9. Thus, the partial structure of compound 1 closely related to bisvertinol [9] was identified. Further examination of the HMBC and COSY correlations (Figure 2) established the second moiety for ring $\mathrm{C}$ to be a cyclohexanone unit, in which the same side chain as that of the first moiety was located at $\mathrm{C}-2\left(\delta_{\mathrm{C}}\right.$ 105.1) based on the HMBC correlations from $\mathrm{H}_{2}-3\left(\delta_{\mathrm{H}} 2.75,2.47, \mathrm{~d}, J=14.6 \mathrm{~Hz}\right)$ and $\mathrm{H}-11\left(\delta_{\mathrm{H}} 6.42, \mathrm{~d}, J\right.$ $=15.2 \mathrm{~Hz})$ to $\mathrm{C}-2$ and $\mathrm{C}-10\left(\delta_{\mathrm{C}} 177.4\right)$. The coexistence of a methyl and a hydroxy group at $\mathrm{C}-4\left(\delta_{\mathrm{C}} 72.8\right)$ was demonstrated by the HMBC correlations from $\mathrm{H}_{3}-16\left(\delta_{\mathrm{C}} 1.22\right.$, s) to $\mathrm{C}-3\left(\delta_{\mathrm{C}} 35.1\right), \mathrm{C}-4$, and $\mathrm{C}-4 \mathrm{a}\left(\delta_{\mathrm{C}}\right.$ 105.9), while the latter was assigned as a hemiketal carbon. Moreover, the HMBC correlations from $\mathrm{H}_{3}-25\left(\delta_{\mathrm{H}} 1.29\right)$ to $\mathrm{C}-1\left(\delta_{\mathrm{C}} 193.6\right), \mathrm{C}-9 \mathrm{~b}\left(\delta_{\mathrm{C}} 59.2\right)$, and C-4a established that the methyl group and ketone were positioned at $\mathrm{C}-9 \mathrm{a}$ and $\mathrm{C}-1$, respectively. Thus, the second moiety was determined to be related to that of bisvertinol. Since the assigned moieties required 11 degrees of unsaturation, the remaining one set was suggested to be contributed by a cyclic unit. The HMBC correlations between $\mathrm{H}_{3}-25$ and C-9a and from H-9a to C-4a and C-9a, in association with the deshielded shifts of C-4a and C-5a, allowed the formation of a tetrahydrofuran ring between rings $\mathrm{A}$ and $\mathrm{C}$.
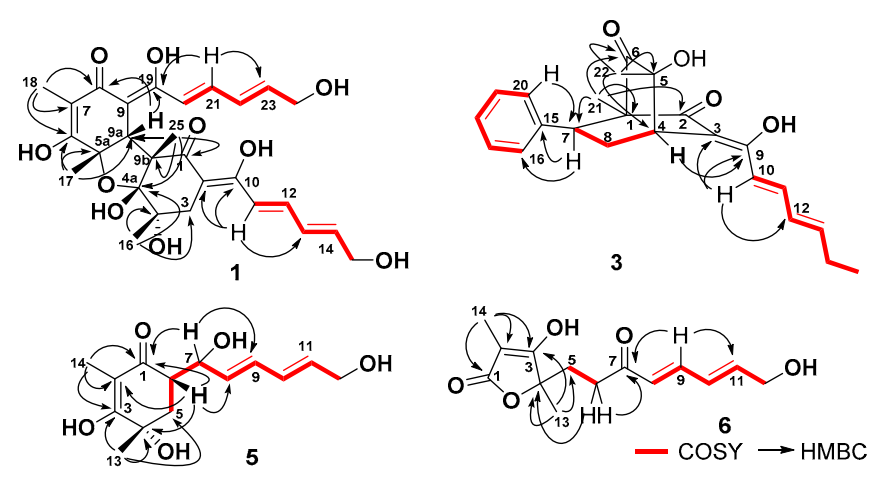

Figure 2. Key COSY and HMBC correlations of 1, 3, 5, and 6.

The relative configuration of compound 1 was inferred from coupling constants and the NOE data. The conjugated double bonds at the side chains were assigned $E$ geometries according to the large $J$ values $\left(15.2 \mathrm{~Hz}\right.$ for $J_{\mathrm{H}-11 / \mathrm{H}-12}, J_{\mathrm{H}-13 / \mathrm{H}-14}, J_{\mathrm{H}-22 / \mathrm{H}-23}$, and $\left.J_{\mathrm{H}-20 / \mathrm{H}-21}\right)$. The cis fusion of rings $\mathrm{A}$ and $\mathrm{B}$ was ascribed to the NOE correlation between $\mathrm{H}_{3}-17$ and $\mathrm{H}-9 \mathrm{a}$, while the cis fusion of rings $\mathrm{B}$ and $C$ was suggested by the minimized energy for $c i$ s and trans junction of rings $B$ and $C$, supporting more stability with lower energy for the cis fusion [23]. Additional NOE interactions from $\mathrm{H}_{3}-25$ to $\mathrm{H}-9 \mathrm{a}, \mathrm{H}-3 \mathrm{~b}\left(\delta_{\mathrm{H}} 2.47, \mathrm{~d}, J=14.6 \mathrm{~Hz}\right)$ and between $\mathrm{H}-3 \mathrm{~b}$ and $\mathrm{H}_{3}-16$ revealed $\mathrm{H}-9 \mathrm{a}$ and $\mathrm{H}_{3}-16$ to be cofacial with $\mathrm{H}_{3}-25$ (Figure 3). Based on the electronic circular dichroism (ECD) exciton chirality rule [24], the negative Cotton effect at $412 \mathrm{~nm}(\Delta \varepsilon-35.5)$, and a positive Cotton effect at $332 \mathrm{~nm}$ $(\Delta \varepsilon+25.5)$ reflected the chromophores of two enol-sorbyl side chains to adopt a counterclockwise fashion (Figure 4), indicating $9 \mathrm{~b} R$ configuration. Accordingly, the remaining stereogenic centers were assumed to be $4 S, 4 a R, 5 a S$, and $9 \mathrm{a} R$ configurations. Comparison of the experimental ECD data with that calculated for the enantiomers of 1 at the B31YP/6-311++G(2d, 2p) level in the gas phase using the B3LYP/6-31G(d) optimized geometries after conformational searches via the MMFF94S force field $[25,26]$ (Figure 4) further supported the configurational assignment. 


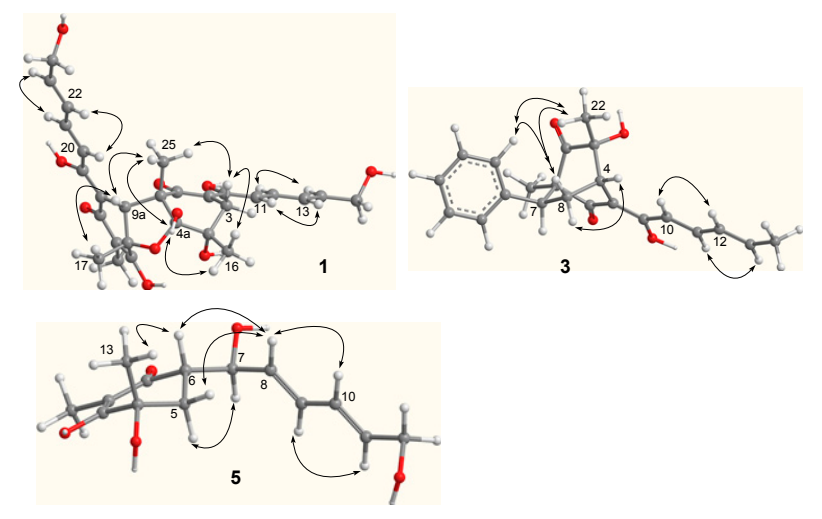

Figure 3. Key nuclear overhauser effect (NOE) interactions of 1, 3, and 5.

The molecular formula of saturnispol B (2) was determined as $\mathrm{C}_{28} \mathrm{H}_{34} \mathrm{O}_{9}$ on the basis of the HRESIMS $\left(m / z 513.2125[\mathrm{M}-\mathrm{H}]^{-}\right.$, calcd for $\left.\mathrm{C}_{28} \mathrm{H}_{33} \mathrm{O}_{9}, 513.2125\right)$ and NMR data, showing the loss of one oxygen atom in comparison with that of compound 1. Comparison of the NMR data (Table 1) and analyses of the two dimensional nuclear magnetic resonance (2D NMR) data revealed that the structure of compound 2 was closely related to that of compound 1 . The main difference was due to the presence of a methyl group $\left(\delta_{\mathrm{H}} 1.87, \mathrm{~d}, J=6.8 \mathrm{~Hz} ; \delta_{\mathrm{C}} 18.1\right)$ at the side chain of ring $\mathrm{C}$ to replace the hydroxymethylene group of 1 . The COSY relationship between $\mathrm{H}_{3}-15\left(\delta_{\mathrm{H}} 1.87, \mathrm{~d}, J=6.8 \mathrm{~Hz}\right)$ and $\mathrm{H}-14$ $\left(\delta_{\mathrm{H}} 6.24, \mathrm{dq}, J=6.8,15.0 \mathrm{~Hz}\right)$ in association with the $\mathrm{HMBC}$ correlations from $\mathrm{H}_{3}-15$ to $\mathrm{C}-13\left(\delta_{\mathrm{C}} 131.1\right)$ and C-14 $\left(\delta_{\mathrm{C}} 139.2\right)$ supported the methyl location. The similar NOE interactions, such as from H-9a $\left(\delta_{\mathrm{H}} 3.75\right)$ to $\mathrm{H}_{3}-17\left(\delta_{\mathrm{H}} 1.45\right)$ and $\mathrm{H}_{3}-25\left(\delta_{\mathrm{H}} 1.34\right)$ and from $\mathrm{H}-3 \mathrm{~b}\left(\delta_{\mathrm{H}} 2.53, \mathrm{~d}, J=14.0 \mathrm{~Hz}\right)$ to $\mathrm{H}_{3}-25$ and $\mathrm{H}_{3}-16\left(\delta_{\mathrm{H}} 1.19\right)$, identified the relative configuration of 2 to be the same as that of $\mathbf{1}$. The similar Cotton effects in the ECD spectra (Figure 4) suggested 2 to be a 15-dehydroxylated analogue of $\mathbf{1}$.

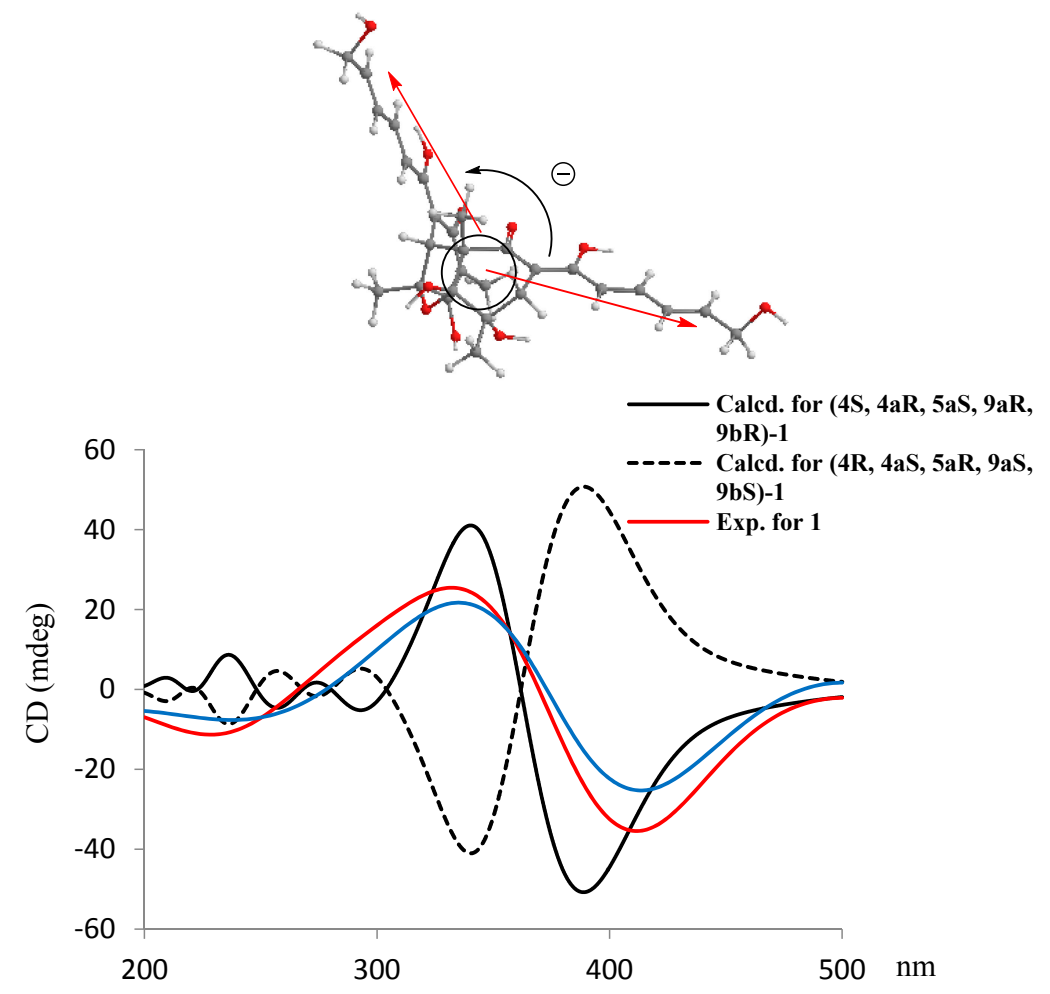

Figure 4. Experimental electronic circular dichroism (ECD) curves of $\mathbf{1}$ and $\mathbf{2}$ and the calculated ECD spectra of $( \pm)-\mathbf{1}$. 
Table 1. ${ }^{1} \mathrm{H}$ and ${ }^{13} \mathrm{C}$ NMR data of $1-2(\delta(\mathrm{ppm}), J(\mathrm{~Hz}))$.

\begin{tabular}{|c|c|c|c|c|}
\hline & $1^{a}$ & & $2^{b}$ & \\
\hline & $\delta_{\mathrm{H}}$ & $\delta_{\mathrm{C}}$ & $\delta_{\mathrm{H}}$ & $\delta_{\mathrm{C}}$ \\
\hline 1 & & 193.6 & & 193.1 \\
\hline 2 & & 105.1 & & 104.8 \\
\hline 3 & 2.75, d (14.6) 2.47, d (14.6) & 35.1 & $2.83, \mathrm{~d}(14.0) 2.53, \mathrm{~d}(14.0)$ & 35.6 \\
\hline 4 & & 72.8 & & 72.8 \\
\hline $4 \mathrm{a}$ & & 105.9 & & 106.1 \\
\hline $5 a$ & & 79.2 & & 78.9 \\
\hline 6 & & 168.3 & & 166.7 \\
\hline 7 & & 109.3 & & 108.9 \\
\hline 8 & & 191.9 & & 191.7 \\
\hline 9 & & 101.7 & & 101.6 \\
\hline $9 \mathrm{a}$ & $3.67, \mathrm{~s}$ & 53.7 & $3.75, \mathrm{~s}$ & 53.8 \\
\hline $9 b$ & & 59.2 & & 58.7 \\
\hline 10 & & 177.4 & & 179.2 \\
\hline 11 & $6.42, \mathrm{~d}(15.2)$ & 122.3 & $6.40, \mathrm{~d}(14.4)$ & 121.1 \\
\hline 12 & $7.28, \mathrm{dd}(11.2,15.2)$ & 141.0 & $7.25, \mathrm{dd}(14.4,12.0)$ & 141.9 \\
\hline 13 & $6.54, \mathrm{dd}(11.2,15.2)$ & 128.3 & $6.39, \mathrm{dd}(14.4,12.0)$ & 131.1 \\
\hline 14 & 6.27, dt $(5.2,15.2)$ & 141.8 & $6.24, \mathrm{dq}(14.4,6.8)$ & 139,2 \\
\hline 15 & $4.22, \mathrm{t}(5.2)$ & 61.5 & $1.87, \mathrm{~d}(6.8)$ & 18.1 \\
\hline 16 & $1.22, \mathrm{~s}$ & 21.3 & $1.19, \mathrm{~s}$ & 21.5 \\
\hline 17 & $1.45, \mathrm{~s}$ & 24.5 & $1.45, \mathrm{~s}$ & 25.1 \\
\hline 18 & $1.43, \mathrm{~s}$ & 5.74 & $1.45, \mathrm{~s}$ & 6.2 \\
\hline 19 & & 166.5 & & 167.6 \\
\hline 20 & $6.62, \mathrm{~d}(15.2)$ & 122.5 & $6.72, \mathrm{~d}(14.4)$ & 122.8 \\
\hline 21 & $7.25, \mathrm{dd}(11.2,15.2)$ & 136.9 & $7.25, \mathrm{dd}(14.4,12.0)$ & 137.1 \\
\hline 22 & $6.54, \mathrm{dd}(11.2,15.2)$ & 128.9 & $6.63, \mathrm{dd}(14.4,12.0)$ & 128.6 \\
\hline 23 & $6.18, \mathrm{dt}(5.2,15.2)$ & 138.6 & $6.23, \mathrm{dd}(14.4,4.6)$ & 139.9 \\
\hline 24 & $4.22, \mathrm{~d}(5.2)$ & 61.6 & $4.23, \mathrm{~d}(4.6)$ & 62.1 \\
\hline 25 & $1.29, \mathrm{~s}$ & 18.7 & $1.34, \mathrm{~s}$ & 19.0 \\
\hline
\end{tabular}

Saturnispol C (3) has a molecular formula of $\mathrm{C}_{22} \mathrm{H}_{24} \mathrm{O}_{4}$, as established by the HRESIMS $\left(m / z 351.1600[\mathrm{M}-\mathrm{H}]^{-}\right.$, calcd for $\left.\mathrm{C}_{22} \mathrm{H}_{23} \mathrm{O}_{4}, 351.1596\right)$ and NMR data, containing 11 degrees of unsaturation. The IR absorptions at 3429, 1730, and $1601 \mathrm{~cm}^{-1}$ suggested the presence of hydroxy and ketone groups. The ${ }^{13} \mathrm{C}$ NMR and DEPT spectra exhibited a total of 22 resonances for three methyls, one methylene, 11 methines, and seven quaternary carbons, of which 12 olefinic or aromatic resonances and two ketones were distinguished. A COSY spin system initiated from $\mathrm{H}-10\left(\delta_{\mathrm{H}} 6.30, \mathrm{~d}, J=14.8 \mathrm{~Hz}\right)$ and extended to $\mathrm{H}-14\left(\delta_{\mathrm{H}} 1.94, \mathrm{~d}, J=6.8 \mathrm{~Hz}\right)$, along with the $\mathrm{HMBC}$ correlation from $\mathrm{H}-10$ and a $\mathrm{D}_{2} \mathrm{O}$ exchangeable proton at $\delta_{\mathrm{H}} 14.34(\mathrm{~s})$ to $\mathrm{C}-9\left(\delta_{\mathrm{C}} 167.1\right)$ and $\mathrm{C}-3\left(\delta_{\mathrm{C}} 112.0\right)$, assigned an enolic sorbyl side chain. A cyclohexandione ring was inferred from the HMBC correlations from $\mathrm{H}_{3}-21\left(\delta_{\mathrm{H}} 0.93, \mathrm{~s}\right)$ to $\mathrm{C}-1$ $\left(\delta_{\mathrm{C}} 64.6\right)$ and two ketone carbons $\mathrm{C}-2\left(\delta_{\mathrm{C}} 197.7\right)$ and $\mathrm{C}-6\left(\delta_{\mathrm{C}} 211.7\right), \mathrm{H}_{3}-22\left(\delta_{\mathrm{H}} 1.29, \mathrm{~s}\right)$ to $\mathrm{C}-4\left(\delta_{\mathrm{C}} 40.5\right)$, $\mathrm{C}-5\left(\delta_{\mathrm{C}} 74.8\right)$ and C-6, in addition to the correlation from $\mathrm{H}-4\left(\delta_{\mathrm{H}} 3.32, \mathrm{t}, J=2.8 \mathrm{~Hz}\right)$ to $\mathrm{C}-2, \mathrm{C}-3, \mathrm{C}-5$, and C-6 (Figure 2). These data also revealed the position of the methyl groups at C- 1 and $C-5$ and an enolic sorbyl unit at C-3, respectively. The HMBC correlation from a $\mathrm{D}_{2} \mathrm{O}$ exchangeable proton at $\delta_{\mathrm{H}}$ 2.69 (s) to C-4, C-5, and C-6 showed C-5 to be hydroxylated. Moreover, a mono-substituted phenyl ring was recognized by the spin system of the aromatic protons at $\delta_{\mathrm{H}} 6.98(\mathrm{~d}, J=7.6 \mathrm{~Hz}, 2 \mathrm{H})$ and $7.26(\mathrm{t}$, $J=7.6 \mathrm{~Hz}, 3 \mathrm{H})$. The remaining two alkyl carbons $\mathrm{C}-7\left(\delta_{\mathrm{C}} 47.7\right)$ and $\mathrm{C}-8\left(\delta_{\mathrm{C}} 31.4\right)$ formed a substituted ethyl unit according to the COSY relationship between $\mathrm{H}-7\left(\delta_{\mathrm{H}} 3.15, \mathrm{dd}, J=5.6,10.8 \mathrm{~Hz}\right)$ and $\mathrm{H}_{2}-8$ $\left(\delta_{\mathrm{H}} 1.90,3.05\right)$, while the linkage of the aromatic ring at C-7 was based on the HMBC correlation from H-7 to the aromatic carbons C-15 $\left(\delta_{\mathrm{C}} 141.4\right)$ and C-16/C-20 $\left(\delta_{\mathrm{C}} 128.4\right)$. Diagnostic COSY and HMBC data (Figure 2), such as the HMBC correlation between $\mathrm{H}_{3}-21$ and $\mathrm{C}-7$ and the COSY relationship from $\mathrm{H}_{2}-8$ to $\mathrm{H}-4$ and $\mathrm{H}-7$, confirmed the fusion of an ethylbenzene unit to the cyclohexandione ring by 
the C-1/C-7 and C-4/C-8 linkage. Thus, the planar structure with a bicyclo $(2,2,2)$ octane skeleton was established. The NOE interactions between $\mathrm{H}_{3}-22 / \mathrm{H}-8 \mathrm{~b}\left(\delta_{\mathrm{H}} 3.05\right), \mathrm{H}-8 \mathrm{~b} / \mathrm{H}-16(\mathrm{H}-20)\left(\delta_{\mathrm{H}} 6.98\right)$, and $\mathrm{H}-8 \mathrm{~b} / \mathrm{H}-16(\mathrm{H}-20)$ revealed Me-22 to be spatially approximated to $\mathrm{H}-8 \mathrm{~b}$, while both $\mathrm{H}-8 \mathrm{~b}$ and the aromatic moiety were in the same face (Figure 3 ). In order to assign the absolute configuration, the ECD data of eight isomers with the same planar structure of compound 3 were calculated at the B31YP/6-311++G(2d, 2p) level. As shown in Figure 5, isomers (Figure 5A,C,E,G) with $1 R$ and $4 S$ configurations exhibited a negative Cotton effect (CE) at 300-340 nm and a positive CE at 350-400 $\mathrm{nm}$, whereas the opposite phases were observed in the same range for the isomers with $1 S$ and $4 R$ configurations (Figure 5B,D,F,H) based on the calculated results. Thus, the negative CE at $310 \mathrm{~nm}$ and positive $C E$ at $350 \mathrm{~nm}$ in the ECD spectrum of 3 were in agreement with $1 R$ and $4 S$ configurations. However, the configurational variation at C-5 and C-7 slightly induced the Cotton effects. Based on the NOE correlation mentioned above, the aromatic moiety linked to C-7 was oriented toward the hydroxy-ketone bridge and $\mathrm{OH}-5$ was located on the same side as the unsaturated side chain, thus the stereogenic centers at C-5 and C-7 were assumed to be $5 R$ and $7 S$ configurations.

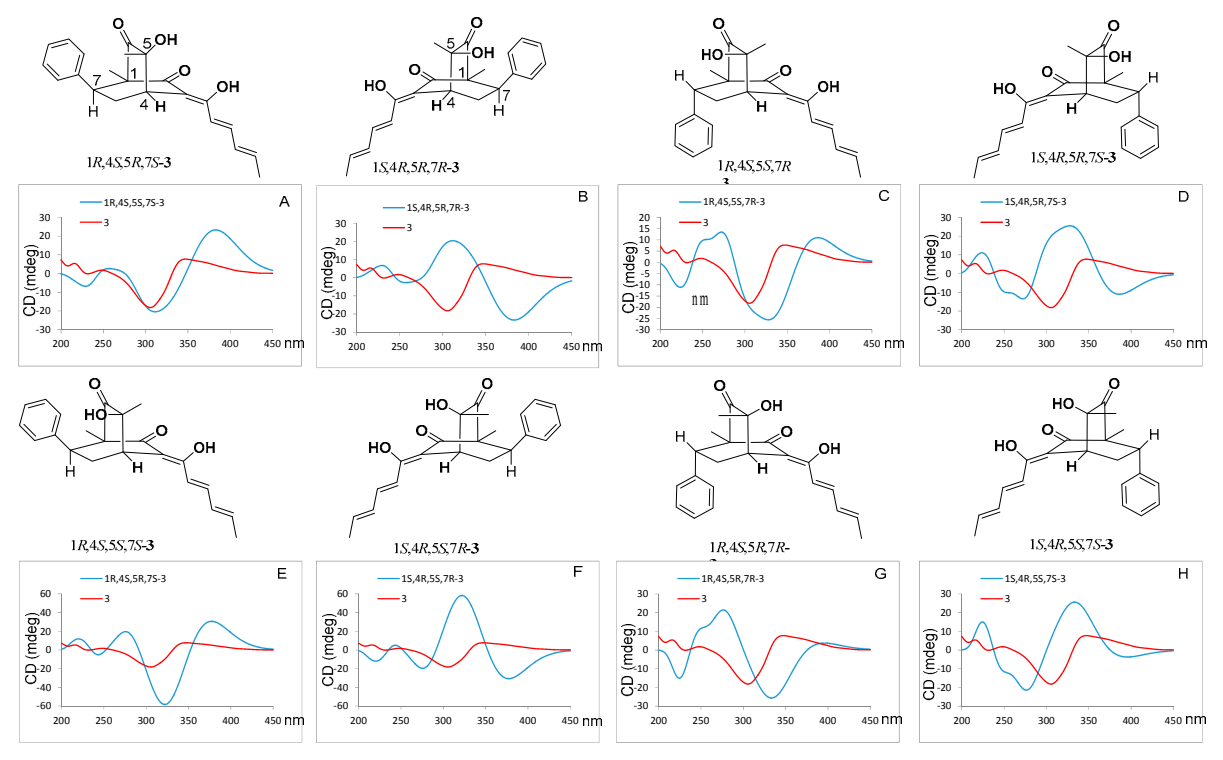

Figure 5. Experimental ECD of $\mathbf{3}$ and calculated ECD spectra of the isomers of 3.

The NMR data of saturnispol D (4) were almost superimposed to those of 3 (Table 2), with the exception of a hydroxymethylene unit in 4 to replace the terminal methyl group at the enolic sorbyl side chain. The COSY relationship between the hydroxymethylene protons $\mathrm{H}_{2}-14\left(\delta_{\mathrm{H}} 4.28, \mathrm{~d}, J=4.4 \mathrm{~Hz}\right)$ and the olefinic proton $\mathrm{H}-13\left(\delta_{\mathrm{H}} 6.39, \mathrm{dt}, J=4.4,15.2 \mathrm{~Hz}\right)$ in addition to the HMBC correlations from $\mathrm{H}_{2}-14$ to $\mathrm{C}-12\left(\delta_{\mathrm{C}} 127.7\right)$ and $\mathrm{C}-13\left(\delta_{\mathrm{C}} 142.9\right)$ indicated 4 to be a 14-hydroxylated analogue of 3 . The comparable ECD data supported both 3 and 4 sharing the same configuration (Figure 6). 
Table 2. ${ }^{1} \mathrm{H}$ and ${ }^{13} \mathrm{C}$ NMR data of 3-4 ( $\left.\delta(\mathrm{ppm}), J(\mathrm{~Hz})\right)$.

\begin{tabular}{|c|c|c|c|c|}
\hline & $3^{a}$ & & $4^{b}$ & \\
\hline 1 & $\delta_{\mathrm{H}}$ & $\begin{array}{c}\delta_{\mathrm{C}} \\
64.6\end{array}$ & $\delta_{\mathrm{H}}$ & $\begin{array}{c}\delta_{\mathrm{C}} \\
64.8\end{array}$ \\
\hline 2 & & $\begin{array}{l}0+.0 \\
197.7\end{array}$ & & 198.4 \\
\hline 3 & & 112.0 & & 112.9 \\
\hline 4 & $3.32, \mathrm{t}(2.8)$ & 40.5 & $3.46, \mathrm{t}(2.8)$ & 40.7 \\
\hline 5 & & 74.8 & & 73.7 \\
\hline 6 & & 211.7 & & 209.2 \\
\hline 7 & $3.15, \mathrm{dd}(10.8,5.6)$ & 47.7 & $3.24, \mathrm{dd}(10.8,6.0)$ & 46.4 \\
\hline 8 & 3.05, ddd $(13.5,10.8,2.8) 1.90$, ddd $(13.5,5.6,2.8)$ & 31.4 & 3.09, ddd $(13.6,10.8,2.8) 1.87$, ddd $(13.6,6.0,2.8)$ & 31.5 \\
\hline 9 & & 167.1 & & 166.8 \\
\hline 10 & $6.30, \mathrm{~d}(14.8)$ & 118.1 & $6.75, \mathrm{~d}(15.2)$ & 120.3 \\
\hline 11 & $7.41, \mathrm{dd}(14.8,10.8)$ & 142.4 & $7.43, \mathrm{dd}(15.2,10.8)$ & 141.0 \\
\hline 12 & $6.33, \mathrm{dd}(14.8,10.8)$ & 130.9 & $6.68, \mathrm{dd}(15.2,10.8)$ & 127.7 \\
\hline 13 & $6.25, \mathrm{dq}(14.8,6.8)$ & 139.7 & $6.39, \mathrm{dt}(15.2,4.4)$ & 142.9 \\
\hline 14 & $1.94, \mathrm{~d}(6.8)$ & 18.9 & $4.28, \mathrm{t}(4.4)$ & 61.7 \\
\hline 15 & & 141.4 & & 142.1 \\
\hline 16 & $6.98, \mathrm{~d}(7.6)$ & 128.4 & $7.07, \mathrm{~d}(7.6)$ & 128.4 \\
\hline 17 & $7.26, \mathrm{t}(7.6)$ & 128.6 & $7.29, \mathrm{t}(7.6)$ & 128.4 \\
\hline 18 & $7.26, \mathrm{t}(7.6)$ & 127.4 & $7.26, \mathrm{t}(7.6)$ & 127.0 \\
\hline 19 & $7.26, \mathrm{t}(7.6)$ & 128.6 & $7.29, \mathrm{t}(7.6)$ & 128.4 \\
\hline 20 & $6.98, \mathrm{~d}(7.6)$ & 128.4 & $7.07, \mathrm{~d}(7.6)$ & 128.4 \\
\hline 21 & $0.93, \mathrm{~s}$ & 10.5 & $0.80, \mathrm{~s}$ & 10.4 \\
\hline 22 & $1.29, \mathrm{~s}$ & 24.4 & $1.26, \mathrm{~s}$ & 23.2 \\
\hline $\mathrm{OH}-5$ & $2.69, \mathrm{~s}$ & & $5.05, \mathrm{~s}$ & \\
\hline OH-9 & $14.34, \mathrm{~s}$ & & $14.40, \mathrm{~s}$ & \\
\hline $\mathrm{OH}-14$ & & & $4.10, \mathrm{t}(4.4)$ & \\
\hline
\end{tabular}

${ }^{\mathrm{a}}$ Measured in $\mathrm{CDCl}_{3} ;{ }^{\mathrm{b}}$ measured in acetone- $d_{6}$.

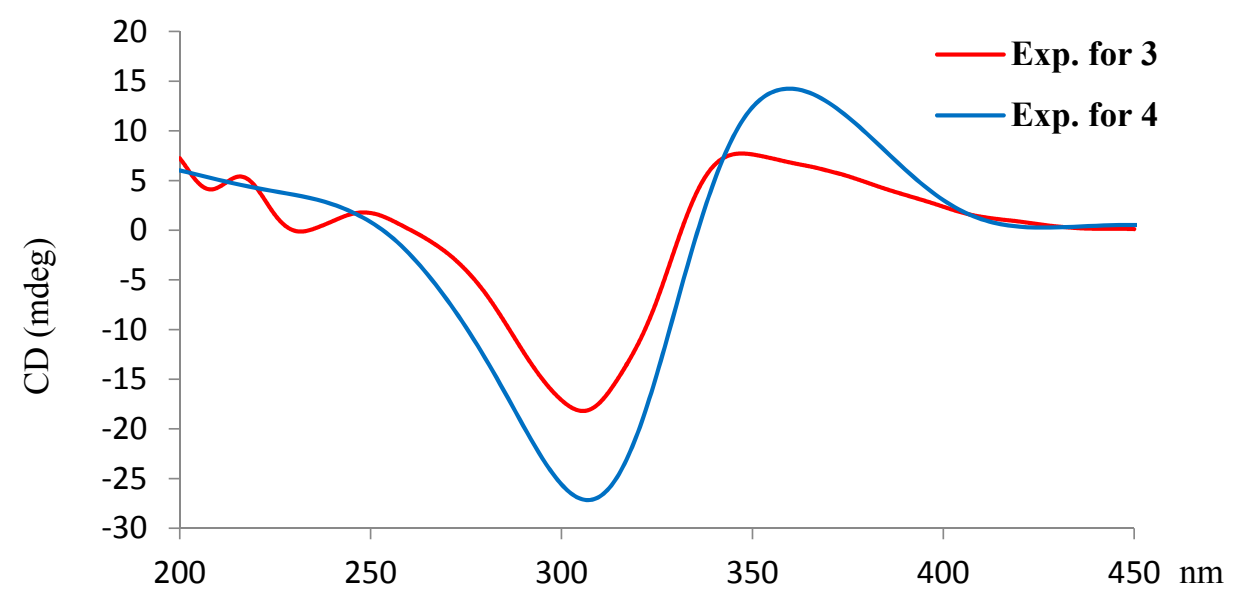

Figure 6. Experimental ECD curves of 3 and 4 .

The molecular formula $\left(\mathrm{C}_{14} \mathrm{H}_{20} \mathrm{O}_{5}\right)$ of saturnispol $\mathrm{E}(5)$ was determined by the HRESIMS $(\mathrm{m} / \mathrm{z}$ 267.1237 [M - H] $]^{-}$, calcd for $\left.\mathrm{C}_{14} \mathrm{H}_{19} \mathrm{O}_{5}, 267.1232\right)$ and NMR data, bearing 5 degrees of unsaturation. IR absorptions at 3365,1740 , and $1623 \mathrm{~cm}^{-1}$ suggested the presence of hydroxy and carbonyl groups. The ${ }^{1} \mathrm{H}$ and ${ }^{13} \mathrm{C}$ NMR data (Tables 3 and 4 ) suggested 5 to be structurally related to sorbicillinol [27]. A cyclohexenone nucleus was demonstrated by the COSY coupling between $\mathrm{H}-6\left(\delta_{\mathrm{H}} 2.69\right.$, ddd, $J=4.8$, 7.4, $12.0 \mathrm{~Hz})$ and $\mathrm{H}_{2}-5\left(\delta_{\mathrm{H}} 1.66,1.98\right)$, and the $\mathrm{HMBC}$ correlations from $\mathrm{H}_{3}-13\left(\delta_{\mathrm{H}} 1.34, \mathrm{~s}\right)$ to $\mathrm{C}-3\left(\delta_{\mathrm{C}}\right.$ $192.2), \mathrm{C}-4\left(\delta_{\mathrm{C}} 71.1\right)$, and $\mathrm{C}-5\left(\delta_{\mathrm{C}} 37.1\right), \mathrm{H}_{3}-14\left(\delta_{\mathrm{H}} 1.68, \mathrm{~s}\right)$ to $\mathrm{C}-1\left(\delta_{\mathrm{C}} 183.2\right), \mathrm{C}-2\left(\delta_{\mathrm{C}} 108.4\right)$, and C-3, in association with the correlations from $\mathrm{H}-6$ to $\mathrm{C}-1, \mathrm{C}-2, \mathrm{C}-4$, and $\mathrm{C}-5$. These findings also allowed the substitution of methyl groups at C-2 and C-4, respectively. The deshielded quaternary carbons C-3 and C-4, as in the case of $\mathbf{1}$, suggested both C-3 and C-4 to be hydroxylated. The COSY relationships established a spin system for a linear side chain of dihydroxyhexadiene, in which a conjugated diene was located between C-8 $\left(\delta_{\mathrm{C}} 131.6\right)$ and C- $11\left(\delta_{\mathrm{C}} 133.5\right)$. The COSY relationships between H-7 $\left(\delta_{\mathrm{H}} 4.49\right.$, 
$\mathrm{t}, J=7.4 \mathrm{~Hz}) / \mathrm{H}-8\left(\delta_{\mathrm{H}} 5.65, \mathrm{dd}, J=7.4,14.4 \mathrm{~Hz}\right)$ and $\mathrm{H}-11\left(\delta_{\mathrm{H}} 5.86, \mathrm{dt}, J=5.6,14.4 \mathrm{~Hz}\right) / \mathrm{H}_{2}-12\left(\delta_{\mathrm{H}} 4.12\right.$, $\mathrm{d}, J=5.6 \mathrm{~Hz})$, in addition to the carbon resonances of $\mathrm{C}-7\left(\delta_{\mathrm{C}} 74.2\right)$ and $\mathrm{C}-12\left(\delta_{\mathrm{C}} 61.7\right)$ as assigned by the HSQC spectrum, indicated both C-7 and C-12 to be hydroxylated. The linkage of the side chain to C-6 $\left(\delta_{\mathrm{C}} 43.9\right)$ was evident from the COSY coupling between $\mathrm{H}-6$ and $\mathrm{H}-7$, as well as the HMBC correlation from $\mathrm{H}-7$ to C-1, C-5 and C- 6 . The E, E geometry of the conjugated diene was deduced by the coupling constants of $J_{\mathrm{H}-8 / \mathrm{H}-9}$ and $J_{\mathrm{H}-10 / \mathrm{H}-11}(15.4 \mathrm{~Hz})$. The NOE interaction between $\mathrm{H}-6$ and $\mathrm{H}_{3}-13$ suggested the same orientation of both protons (Figure 3). The $J_{\mathrm{H}-6 / \mathrm{H}-7}(7.4 \mathrm{~Hz})$ value, in addition to the NOE interaction from $\mathrm{H}-7\left(\delta_{\mathrm{H}} 4.49\right)$ and $\mathrm{H}-8$ to $\mathrm{H}-5 \mathrm{a}\left(\delta_{\mathrm{H}} 1.66\right)$, and that between $\mathrm{H}-6$ and $\mathrm{H}-8$, suggested that the side chain maintained a stable geometry, in which $\mathrm{H}-7$ was trans relative to $\mathrm{H}-6$, while $\mathrm{H}-7$ and $\mathrm{H}-8$ were spatially close to $\mathrm{H}-5 \mathrm{a}$. Thus, the relative configurations of 5 were suggested to be $4 \mathrm{~S}^{*}, 6 \mathrm{~S}^{*}$, and $7 S^{*}$. The ECD data for the stereogenic isomers of $(4 R, 6 R, 7 R)-5$ and $(4 S, 6 S, 7 S)$-5 were calculated. Comparison of the experimental ECD data with those calculated for the isomers confirmed 5 to be in $4 S, 6 S$, and $7 S$ configurations (Figure 7).

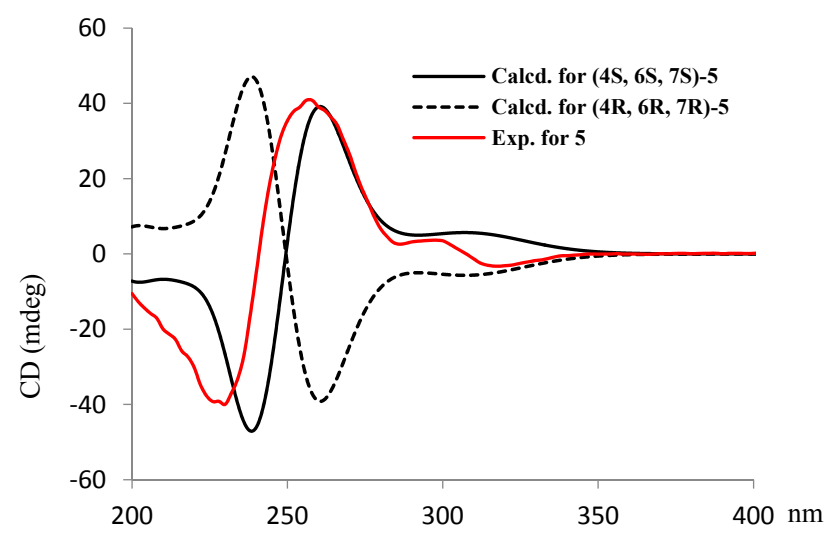

Figure 7. Experimental ECD curves of 5 and the calculated ECD spectra of $( \pm)-\mathbf{5}$.

Table 3. ${ }^{1} \mathrm{H}$ NMR data of 5-8 ( $\delta$ (ppm), J (Hz), $\left.400 \mathrm{MHz}\right)$.

\begin{tabular}{|c|c|c|c|c|}
\hline & $5^{a}$ & $6^{a}$ & $7^{b}$ & $8^{a}$ \\
\hline 4 & & & $6.01, \mathrm{~s}$ & $6.08, \mathrm{~s}$ \\
\hline 5 & $1.96, \mathrm{dd}(12.8,4.8) 1.66, \mathrm{dd}(12.8,12.0)$ & $2.07, \mathrm{t}(7.6)$ & & \\
\hline 6 & 2.69, ddd $(12.0,7.4,4.8)$ & $2.50, \mathrm{t}(7.6)$ & $6.11, \mathrm{~d}(16.0)$ & $6.19, \mathrm{~d}(15.2)$ \\
\hline 7 & $4.49, \mathrm{t}(7.4)$ & & $6.63, \mathrm{dt}(16.0,7.2)$ & $7.06, \mathrm{dd}(15.2,10.8)$ \\
\hline 8 & $5.65, \mathrm{dd}(14.4,7.4)$ & $6.18, \mathrm{~d}(16.0)$ & $2.32, \mathrm{dt}(7.2,7.6)$ & $6.45, \mathrm{dd}(15.2,10.8)$ \\
\hline 9 & $6.31, \mathrm{dd}(14.4,10.6)$ & $7.25, \mathrm{dd}(16.0,10.6)$ & $1.71, \mathrm{tt}(7.6,6.4)$ & $6.15, \mathrm{dt}(15.2,5.0)$ \\
\hline 10 & $6.29, \mathrm{dd}(14.4,10.6)$ & $6.47, \mathrm{dd}(16.0,10.6)$ & $3.61, \mathrm{t}(6.4)$ & $4.20, \mathrm{~d}(5.0)$ \\
\hline 11 & $5.86, \mathrm{dt}(14.4,5.6)$ & 6.36, dt $(16.0,4.6)$ & $1.89, \mathrm{~s}$ & $1.90, \mathrm{~s}$ \\
\hline 12 & $4.12, \mathrm{~d}(5.6)$ & $4.22, \mathrm{~d}(4.6)$ & & \\
\hline 13 & $1.34, \mathrm{~s}$ & $1.44, \mathrm{~s}$ & & \\
\hline 14 & $1.68, \mathrm{~s}$ & $1.66, \mathrm{~s}$ & & \\
\hline
\end{tabular}


Table $4 .{ }^{13} \mathrm{C}$ NMR data of $5-8$.

\begin{tabular}{ccccc}
\hline & $\mathbf{5}^{\mathbf{a}}$ & $\mathbf{6}^{\mathbf{a}}$ & $\mathbf{7}^{\mathbf{b}}$ & $\mathbf{8}^{\mathbf{a}}$ \\
\hline 1 & 183.2 & 176.8 & 164.4 & 166.7 \\
2 & 108.4 & 93.6 & 98.9 & 99.2 \\
3 & 192.2 & 180.8 & 156.1 & 156.5 \\
4 & 71.1 & 83.0 & 99.6 & 101.4 \\
5 & 37.1 & 30.6 & 164.8 & 167.1 \\
6 & 43.9 & 33.7 & 122.2 & 121.9 \\
7 & 74.2 & 200.6 & 137.1 & 134.0 \\
8 & 131.6 & 128.5 & 28.8 & 128.4 \\
9 & 132.3 & 142.9 & 31.8 & 138.4 \\
10 & 129.4 & 127.4 & 60.7 & 61.6 \\
11 & 133.5 & 143.6 & 8.0 & 7.2 \\
12 & 61.7 & 61.4 & & \\
13 & 24.0 & 22.2 & & \\
14 & 6.4 & 4.6 & & \\
\hline \multicolumn{5}{c}{ Measured in $\mathrm{CD}_{3} \mathrm{OD}^{\text {a }}{ }^{\mathrm{b}}$ measured in acetone- $d_{6}}$.
\end{tabular}

Saturnispol F (6) has a molecular formula of $\mathrm{C}_{14} \mathrm{H}_{18} \mathrm{O}_{5}$, as established by the HRESIMS $(\mathrm{m} / \mathrm{z}$ 265.1073 [M - H] $]^{-}$, calcd for $\left.\mathrm{C}_{14} \mathrm{H}_{17} \mathrm{O}_{5}, 265.1076\right)$ and NMR data. The ${ }^{13} \mathrm{C}$ NMR and DEPT spectra displayed 14 carbon resonances, including six olefinic carbons, two carbonyl carbons, and three methylene carbons. The IR absorptions at 1737 and $1655 \mathrm{~cm}^{-1}$ suggested the presence of an unsaturated lactone. The ${ }^{1} \mathrm{H}$ NMR spectrum exhibited the proton resonances, including two methyl singlets at $\delta_{\mathrm{H}}$ $1.44\left(\mathrm{~s}, \mathrm{H}_{3}-13\right)$ and $\delta_{\mathrm{H}} 1.66\left(\mathrm{~s}, \mathrm{H}_{3}-14\right)$. The ${ }^{1} \mathrm{H}_{-}{ }^{1} \mathrm{H}$ COSY spectrum correlated four conjugated olefinic protons for a diene unit from $\mathrm{H}-8\left(\delta_{\mathrm{H}} 6.18, \mathrm{~d}, J=16.0 \mathrm{~Hz}\right)$ to $\mathrm{H}-11\left(\delta_{\mathrm{H}} 6.36, \mathrm{dt}, J=4.6,16.0 \mathrm{~Hz}\right)$ and the protons for two methylenes $\mathrm{H}_{2}-5\left(\delta_{\mathrm{H}} 2.07, \mathrm{t}, J=7.6 \mathrm{~Hz}\right)$ and $\mathrm{H}_{2}-6\left(\delta_{\mathrm{H}} 2.50, \mathrm{t}, J=7.6 \mathrm{~Hz}\right)$, while $\mathrm{H}-11$ extended its COSY correlation with the methylene protons at $\delta_{\mathrm{H}} 4.22(\mathrm{~d}, J=4.6 \mathrm{~Hz})$. These data are in agreement with the HMBC correlations from a ketone carbon $\left(\delta_{\mathrm{C}} 200.6, \mathrm{C}-7\right)$ to $\mathrm{H}_{2}-5, \mathrm{H}_{2}-6, \mathrm{H}-8$, and $\mathrm{H}-9\left(\delta_{\mathrm{H}} 7.25, \mathrm{dd}, J=10.6,16.0 \mathrm{~Hz}\right)$, which established a 11-hydroxy-7-oxo-8,10-octadienyl side chain. Th remaining NMR resonances were attributed to C-1 $\left(\delta_{\mathrm{C}} 176.8\right), \mathrm{C}-2\left(\delta_{\mathrm{C}} 93.6\right), \mathrm{C}-3\left(\delta_{\mathrm{C}} 180.8\right), \mathrm{C}-4\left(\delta_{\mathrm{C}}\right.$ 83.0), and two methyl groups. The HMBC spectrum correlated $\mathrm{H}_{3}-13$ with $\mathrm{C}-3$ and $\mathrm{C}-4$ and $\mathrm{H}_{3}-14$ with C-1, C-2, and C-3, in association with the degrees of the molecular unsaturation, allowed the assignment of a 2,4-dimethyl- $\gamma$-lactone unit, while the remaining $\mathrm{OH}$ group was positioned at the quaternary carbon $\mathrm{C}-3$. The linkage of the side chain to $\mathrm{C}-4$ in the $\gamma$-lactone ring was evident from additional HMC correlations from $\mathrm{H}_{3}-13$ to $\mathrm{C}-5\left(\delta_{\mathrm{C}} 30.6\right)$ and $\mathrm{H}_{2}-5$ to $\mathrm{C}-3$ and $\mathrm{C}-4$. Thus, the planar structure of 6 was closely related to vertinolide [28], except for the substitution of a hydroxy group at $\mathrm{C}-12\left(\delta_{\mathrm{C}} 61.4\right)$. The $E, E$ geometry of the diene was evidenced by the coupling constants of $J_{\mathrm{H}-8 / \mathrm{H}-9}$ and $J_{\mathrm{H}-10 / \mathrm{H}-11}(16.0 \mathrm{~Hz})$. Regarding the absolute configuration, the comparable specific rotation between $\mathbf{6}\left([\alpha]_{\mathrm{D}}^{15}, \mathrm{CHCl}_{3}\right)$ and $(S)-(-)$-vertinolide [29] suggested the $4 S$ configuration of $\boldsymbol{6}$. This depiction was confirmed by the experimental ECD data, which agreed with those calculated for the $4 S$ isomer (Figure 8).

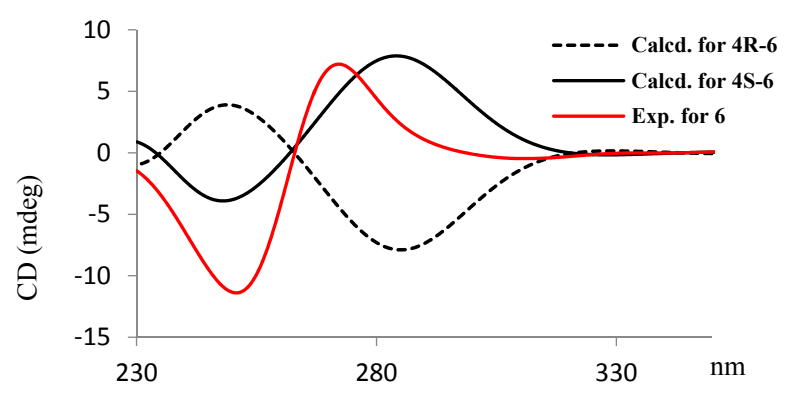

Figure 8. Experimental and calculated ECD spectra of 6 . 
The HRESIMS data provided the molecular formula of saturnispol $\mathrm{G}(7)$ as $\mathrm{C}_{11} \mathrm{H}_{14} \mathrm{O}_{4}$, requiring 5 degrees of unsaturation. The HSQC spectrum assigned all protons and their corresponding carbons. The ${ }^{1} \mathrm{H}$ NMR spectrum showed three olefinic protons, a methyl singlet, and six alkyl protons, while the ${ }^{13} \mathrm{C}$ NMR and DEPT spectra afforded a methyl, three methylenes, six olefinic resonances, and a carbonyl carbon. Analyses of the $\mathrm{HMBC}$ data, such as the correlations from $\mathrm{H}_{3}-11\left(\delta_{\mathrm{H}} 1.89, \mathrm{~s}\right)$ to $\mathrm{C}-1\left(\delta_{\mathrm{C}} 164.4\right), \mathrm{C}-2\left(\delta_{\mathrm{C}} 98.9\right)$, and C-3 $\left(\delta_{\mathrm{C}} 156.1\right)$ and from H-4 $\left(\delta_{\mathrm{H}} 6.01, \mathrm{~s}\right)$ to C-2 and C-5 $\left(\delta_{\mathrm{C}} 164.8\right)$, suggested a 2-methyl-3-hydroxypyranone nucleus. The COSY relationships provided a spin system for a hydroxylated pentene side chain, in which the hydroxy group was positioned at C-10 $\left(\delta_{\mathrm{C}} 60.7\right)$, based on the COSY relationship between $\mathrm{H}_{2}-10\left(\delta_{\mathrm{H}} 3.61, \mathrm{t}, J=6.4 \mathrm{~Hz}\right)$ and $\mathrm{H}_{2}-9\left(\delta_{\mathrm{H}} 1.71, \mathrm{tt}, J=6.4\right.$, $7.6 \mathrm{~Hz})$. The HMBC correlation of the olefinic proton $\mathrm{H}-6\left(\delta_{\mathrm{H}} 6.11, \mathrm{~d}, J=16.0 \mathrm{~Hz}\right)$ to C-4 $\left(\delta_{\mathrm{C}} 99.6\right)$ and $\mathrm{C}-5\left(\delta_{\mathrm{C}} 164.8\right)$ allowed the side chain to be linked to $\mathrm{C}-5$. The $6 E$ geometry was identified by the $J_{\mathrm{H}-6 / \mathrm{H}-7}(16.0 \mathrm{~Hz})$ value.

The structure of saturnispol H (8) was determined as a 6,8-diene analogue of 7, based on the similar NMR data of both compounds (Tables 3 and 4) with the exception of an additional double bond C-8 $\left(\delta_{\mathrm{C}} 128.4\right) / \mathrm{C}-9\left(\delta_{\mathrm{C}} 138.4\right)$. The COSY correlation established a spin system of a side chain from H-6 to $\mathrm{H}_{2}-10\left(\delta_{\mathrm{H}} 4.20, \mathrm{~d}, J=5.0 \mathrm{~Hz}\right)$. The geometry of the diene unit was in $6 E, 8 E$ according to the $J$ values.

Biogenetically, sorbicillin-derived sorbicillinol is postulated as the precursor to generate the isolated compounds. The bisorbicillinoids $\mathbf{1}$ and $\mathbf{2}$ were supposed to be derived by the condensation of two sorbicillinol units via a Michael-type condensation, an approach similar to the biogenetic formation of bisvertinolone [30]. The hydroxylation at the terminal of the side chain was likely induced by the P450 enzyme. The $(2+4)$ "Diels-Alder" cycloaddition [31] of sorbicillinol with a phenylethylene generated 3 , followed by hydroxylation to yield 4 . Compound 5 was likely generated from sorbicillinol by olefinic reduction and enol rearrangement. The unsaturated $\gamma$-lactone was supposed to be originated from sorbicillinol through reduction, hemiketal formation, retro-Claisen cleavage [32], and terminal hydroxylation. Neumann [33] postulated that the pyrone unit was derived from sorbicillinol by multiple steps. We suggest oxidation to lose a $C_{3}$ unit in sorbicillinol to produce 8 and 7 (Scheme 1).

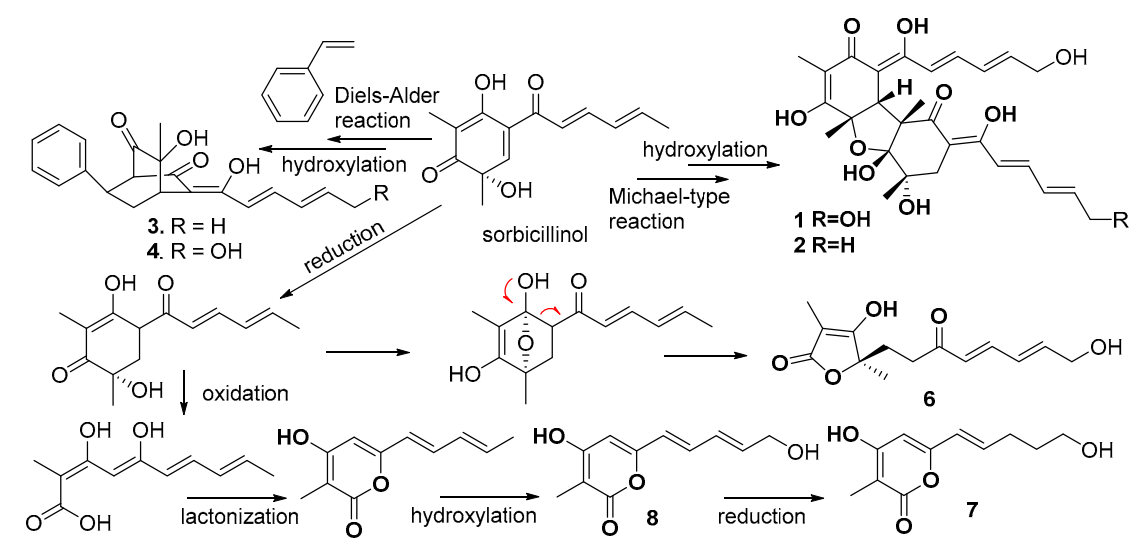

Scheme 1. Postulation of the biogenetic relationship among the isolated compounds.

All compounds were evaluated for antimicrobial activity toward several bacterial strains, including Staphylococcus aureus ATCC 29213, vancomycin-resistant Enterococci faecalis A4 (VRE), Bacillus subtilis ATCC 6051, Pseudomonas aeruginosa 14, and Klebsiella pneumoniae WNX-1. As shown in Table 5, the unsaturated $\gamma$-lactone 6 exhibited significant inhibition against a panel of bacterial strains, of which the MIC value toward VRE was $1.63 \mu \mathrm{g} / \mathrm{mL}$. The pyrone derivative 8 selectively inhibited VRE and B. subtilis with an MIC value of $12.9 \mu \mathrm{g} / \mathrm{mL}$. The remaining compounds showed MIC values higher than $64 \mu \mathrm{g} / \mathrm{mL}$. 
Table 5. Antimicrobial activities of compounds 1-8.

\begin{tabular}{cccccc}
\hline \multirow{2}{*}{ Compounds } & \multicolumn{5}{c}{ MIC $(\mu \mathrm{g} / \mathrm{mL})$} \\
\cline { 2 - 5 } & S. Aureus & VRE & B. Subtilis & P. Aeruginosa & K. Pneumonica \\
\hline $\mathbf{1}$ & $>64$ & $>64$ & $>64$ & $>64$ & $>64$ \\
$\mathbf{2}$ & $>64$ & $>64$ & $>64$ & $>64$ & $>64$ \\
$\mathbf{3}$ & $>64$ & $>64$ & $>64$ & $>64$ & $>64$ \\
$\mathbf{4}$ & $>64$ & $>64$ & $>64$ & $>64$ & $>64$ \\
$\mathbf{5}$ & $>64$ & $>64$ & $>64$ & $>64$ & $>64$ \\
$\mathbf{6}$ & 3.32 & 1.63 & $>64$ & 6.65 & 6.65 \\
$\mathbf{7}$ & $>64$ & $>64$ & $>64$ & $>64$ & $>64$ \\
$\mathbf{8}$ & $>64$ & 12.9 & 12.9 & $>64$ & $>64$ \\
ciprofloxacin & 0.125 & ND & 0.125 & ND & ND \\
colistin & ND & ND & ND & 0.125 & 0.125 \\
bacaucin & ND & 16 & ND & ND & ND \\
\hline
\end{tabular}

MIC: minimum inhibitory concentrations, ND = no detection.

\section{Discussion}

Fungal species of the Trichoderma genus are recognized as biological control agents against plant-associated fungal pathogens, with the biological effects of these fungal strains due to the profiles of fungus-derived metabolites. Pentylpyrone from T. koningii inhibited the growth of several soilborne plant pathogens [15], while sorbicillin-related analogues exerted radical scavenging and other bioactivities [34]. These findings suggested that the Trichoderma fungus inhabiting the host sponges produces sorbicillinoids, which may play chemoecological role. In the present work, the fungus host, sponge Dictyonella incisa, was reported to produce conjugated and degraded sterols and fatty acids without cytotoxicity [35-37]. These data, along with the various bioactivities of sorbicillinoids, suggested that the endophytic fungus T. saturnisporum produced sorbicillinoid-based derivatives to help the host sponge in its defense against pathogenic invasion. For a pharmaceutical point of view, the pathogenic bacterium E. faecium is often resistant to vancomycin and ampicillin, and is difficult to treat by antibacterial agents [38]. The potent anti-VRE effect of the unsaturated $\gamma$-lactone (6) provides a new natural scaffold for further development as a promising anti-VRE lead after structural modification.

\section{Materials and Methods}

\subsection{General Experimental Procedures}

Optical rotations were measured on a Rudolph IV Autopol automatic polarimeter. IR spectra were recorded on a Thermo Nicolet Nexus $470 \mathrm{FT}-\mathrm{IR}$ spectrometer. ${ }^{1} \mathrm{H}$ and ${ }^{13} \mathrm{C} \mathrm{NMR}$ as well as $2 \mathrm{D}$ NMR spectra were recorded on a Bruker Avance $400 \mathrm{NMR}$ spectrometer $\left(400 \mathrm{MHz}\right.$ for ${ }^{1} \mathrm{H}$ and $100 \mathrm{MHz}$ for ${ }^{13} \mathrm{C}$, respectively). Chemical shifts are expressed in $\delta(\mathrm{ppm})$, referenced to the solvent peaks at $\delta_{\mathrm{H}}$ 3.31 and $\delta_{\mathrm{C}} 49.3$ for $\mathrm{CD}_{3} \mathrm{OD}$ or $\delta_{\mathrm{H}} 2.05$ and $\delta_{\mathrm{C}} 30.2,206.8$ for acetone- $d_{6}$, and coupling constants are in $\mathrm{Hz}$. The temperature for NMR measurement is $298 \mathrm{~K}$, the coupling constant for HMBC experiments is optimized as $8 \mathrm{~Hz}$, and the mixing time used for ROESY experiments is $2 \mathrm{~s}$. HREIMS spectra were obtained from an Autospec Ultima-TOF spectrometer. TLC: Precoated Si gel G plates (Qingdao Marine Chemical Factory, Qingdao, China). Silica gels (200-300 mesh, Qingdao Marine Chemistry Co., Ltd.) and octadecylsilyl silica (ODS) (YMC) were used for column chromatography. Semi-preparative HPLC chromatography was performed on an Alltech instrument (426-HPLC pump) equipped with an Alltech uvis-200 detector at $210 \mathrm{~nm}$, and semi-preparative reversed-phase columns (YMC-packed $\mathrm{C}_{18}, 5 \mu \mathrm{m}, 250 \mathrm{~mm} \times 10 \mathrm{~mm}$ ) were purchased from YMC Co LTD (Kyoto, Japan). ECD spectra were obtained on a Jasco J-810 spectropolarimeter. The bacterium strains (Staphylococcus aureus ATCC 29213, Bacillus subtilis ATCC 6051) were purchased from American Type Culture Collection (ATCC), and vancomycin-resistant Enterococci faecalis A4 (VRE), Pseudomonas aeruginosa 14, and Klebsiella 
pneumoniae WNX-1 were supplied by Prof. Kui Zhu (the Microbiology Center, Agriculture University of China, Beijing, China).

\subsection{Fungal Strain}

The fungus, strain DI-IA, was isolated from the sponge Dictyonella incisa collected at a depth of $10 \mathrm{~m}$ in the Seferihisar bay of Turkey. It was identified as Trichoderma saturnisporum on the basis of its ribosomal internal transcribed spacers (ITS) and the 5.8S ribosomal RNA gene (ITS1-5.8S-ITS2). Working stocks were prepared on potato dextrose agar slants stored at $4{ }^{\circ} \mathrm{C}$ in our laboratory.

\subsection{Fermentation, Extraction, and Isolation}

The fermentation was carried out in Fernbach flasks $(500 \mathrm{~mL})$, which contained $80 \mathrm{~g}$ of rice. Distilled $\mathrm{H}_{2} \mathrm{O}(120 \mathrm{~mL})$ was added to the flask, and the contents were soaked overnight before autoclaving at $15 \mathrm{psi}$ for $30 \mathrm{~min}$. After cooling to room temperature (rt), each flask was inoculated with $5.0 \mathrm{~mL}$ of the spore inoculums and incubated at $25^{\circ} \mathrm{C}$ for 40 days. The fermented material was extracted successively with EtOAc $(3 \times 500 \mathrm{~mL})$, and then evaporated to dryness under vacuum to afford a crude extract. The crude extracts were tested against $S$. aureus and showed an inhibitory effect with an MIC value of $64 \mu \mathrm{g} / \mathrm{mL}$. Thus, the EtOAc extract was detected by the ${ }^{1} \mathrm{H}$ NMR spectrum, showing the rich conjugated olefinic resonances in the range of 5-7 ppm.

The EtOAc extract (1.1 g) extract was subjected to silica gel vacuum liquid chromatography (VLC), eluting with a gradient of petroleum/ethyl acetate (from 50:0 to 1:1, v:v) and $\mathrm{CH}_{2} \mathrm{Cl}_{2}-\mathrm{MeOH}$ (from 20:1 to $10: 1, v: v)$ to obtain nine fractions (F1-F9). F9 (90 mg) was subjected to semi-preparative HPLC (ODS, $26 \times 310 \mathrm{~mm}, 2 \mathrm{~mL} / \mathrm{min}$, UV detection at $400 \mathrm{~nm})$ with $\mathrm{MeOH}-\mathrm{H}_{2} \mathrm{O}-\mathrm{TFA}(60: 40: 0.1)$ as a mobile phase to give $2(15 \mathrm{mg})$. F8 (120 mg) was purified by RP- HPLC (YMC-packed C18, $5 \mu \mathrm{m}, 250 \times 10 \mathrm{~mm}$, $2 \mathrm{~mL} / \mathrm{min}$, UV detection at $210 \mathrm{~nm}$ ), eluting with $\mathrm{MeOH}^{-\mathrm{H}_{2} \mathrm{O}-\mathrm{TFA}}$ (45:55:0.1) to yield 5 (4.1 mg), 6 (11.1 mg), 7 (6.9 mg), and 8 (7.6 mg). F7 (150 mg) was separated by RP-HPLC (YMC-packed C 18 , $5 \mu \mathrm{m}, 250 \times 10 \mathrm{~mm}, 2 \mathrm{~mL} / \mathrm{min}$, UV detection at $210 \mathrm{~nm}$ ) eluting with $\mathrm{MeOH}-\mathrm{H}_{2} \mathrm{O}-\mathrm{TFA}$ (71:29:0.1) to obtain $\mathbf{1}$ (10 mg), 4 (4.2 mg), and 3 (7.5 mg). The IR, HRESIMS, 1D and 2D NMR spectra of the compounds were provided in the Supporting Information Figures S1-S62.

Saturnispol A (1): red oil. $[\alpha]_{\mathrm{D}}=-445.5(c 1.1, \mathrm{MeOH}) ; \mathrm{UV}(\mathrm{MeOH})(\log \varepsilon) \lambda_{\max } 228,272,32,401 \mathrm{~nm}$; $\mathrm{IR}(\mathrm{MeOH}) \gamma_{\max } 3380,2919,2850,1738,1614,1555,1366 \mathrm{~cm}^{-1} ;{ }^{1} \mathrm{H}$ NMR $\left(\mathrm{CD}_{3} \mathrm{OD}, 400 \mathrm{MHz}\right)$ and ${ }^{13} \mathrm{C}$ NMR $\left(\mathrm{CD}_{3} \mathrm{OD}, 100 \mathrm{MHz}\right)$ data, see Table 1 ; HRESIMS $m / z 529.2069[\mathrm{M}-\mathrm{H}]^{-}$(calcd for $\mathrm{C}_{28} \mathrm{H}_{33} \mathrm{O}_{10}$, 529.2074).

Saturnispol B (2): yellow oil. $[\alpha]_{\mathrm{D}}=-367.3(c 1.1, \mathrm{MeOH})$; UV (MeOH) $(\log \varepsilon) \lambda_{\max } 238,278,336$, $402 \mathrm{~nm}$; IR (MeOH) $v_{\max } 3404,2970,2928,1736,1714,1614,1560 \mathrm{~cm}^{-1} ;{ }^{1} \mathrm{H}$ NMR (acetone- $d_{6}, 400 \mathrm{MHz}$ ) and ${ }^{13} \mathrm{C}$ NMR (acetone- $d_{6}, 100 \mathrm{MHz}$ ) data, see Table 1 ; HRESIMS $m / z 513.2125[\mathrm{M}-\mathrm{H}]^{-}$(calcd for $\mathrm{C}_{28} \mathrm{H}_{33} \mathrm{O}_{9}$, 513.2125).

Saturnispol C (3): yellow oil. $[\alpha]_{\mathrm{D}}=+20.0(c 0.12, \mathrm{MeOH}) ; \mathrm{UV}(\mathrm{MeOH})(\log \varepsilon) \lambda_{\max } 367 \mathrm{~nm}$; IR $(\mathrm{MeOH})$ $v_{\max } 3429,2925,2853,1730,1712,1601,1453,1377,1230 \mathrm{~cm}^{-1} ;{ }^{1} \mathrm{H} \mathrm{NMR}\left(\mathrm{CDCl}_{3}, 400 \mathrm{MHz}\right)$ and ${ }^{13} \mathrm{C}$ NMR $\left(\mathrm{CDCl}_{3}, 100 \mathrm{MHz}\right)$ data, see Table 2; HRESIMS $m / z 351.1600[\mathrm{M}-\mathrm{H}]^{-}$(calcd for $\mathrm{C}_{22} \mathrm{H}_{23} \mathrm{O}_{4}$, 351.1596).

Saturnispol D (4): yellow oil. $[\alpha]_{\mathrm{D}}=+26.0(c 0.08, \mathrm{MeOH})$; UV (MeOH) $(\log \varepsilon) \lambda_{\max } 339,360 \mathrm{~nm}$; IR (MeOH) $v_{\max } 3439,2926,2854,1771,1732,1617,1440,1390 \mathrm{~cm}^{-1} ;{ }^{1} \mathrm{H}$ NMR (acetone- $d_{6}, 400 \mathrm{MHz}$ ) and ${ }^{13} \mathrm{C}$ NMR (acetone- $d_{6}, 100 \mathrm{MHz}$ ) data, see Table 2; HRESIMS $m / z 367.1544[\mathrm{M}-\mathrm{H}]^{-}$(calcd for $\left.\mathrm{C}_{22} \mathrm{H}_{23} \mathrm{O}_{5}, 367.1545\right)$.

Saturnispol E (5): yellow oil. $[\alpha]_{\mathrm{D}}=+43.1\left(c\right.$ 1.3, MeOH); UV (MeOH) $(\log \varepsilon) \lambda_{\max } 229,264 \mathrm{~nm}$; IR $(\mathrm{MeOH}) v_{\max } 3365,2927,1740,1713,1623,1454 \mathrm{~cm}^{-1} ;{ }^{1} \mathrm{H}$ NMR $\left(\mathrm{CD}_{3} \mathrm{OD}, 400 \mathrm{MHz}\right)$ and ${ }^{13} \mathrm{C} \mathrm{NMR}$ $\left(\mathrm{CD}_{3} \mathrm{OD}, 100 \mathrm{MHz}\right)$ data, see Tables 3 and 4; HRESIMS $m / z 267.1237[\mathrm{M}-\mathrm{H}]^{-}$(calcd for $\mathrm{C}_{14} \mathrm{H}_{19} \mathrm{O}_{5}$, 267.1232). 
Saturnispol $F$ (6): light yellow oil. $[\alpha]_{\mathrm{D}}=-15\left(c 1.0, \mathrm{CHCl}_{3}\right)$; UV (MeOH) $(\log \varepsilon) \lambda_{\max } 250,272,372 \mathrm{~nm}$; IR $(\mathrm{MeOH}) v_{\max } 3422,2924,2853,1737,1655,1640,1366 \mathrm{~cm}^{-1} ;{ }^{1} \mathrm{H}$ NMR $\left(\mathrm{CD}_{3} \mathrm{OD}, 400 \mathrm{MHz}\right)$ and ${ }^{13} \mathrm{C}$ NMR $\left(\mathrm{CD}_{3} \mathrm{OD}, 100 \mathrm{MHz}\right)$ data, see Tables 3 and 4; HRESIMS $m / z 265.1073$ [M $\left.-\mathrm{H}\right]^{-}$(calcd for $\left.\mathrm{C}_{14} \mathrm{H}_{17} \mathrm{O}_{5}, 265.1076\right)$.

Saturnispol G (7): yellow oil. UV (MeOH) $(\log \varepsilon) \lambda_{\max } 222,324 \mathrm{~nm}$; IR (MeOH) $v_{\max } 3437,2923,1670$, $1631,1570,1411 \mathrm{~cm}^{-1} ;{ }^{1} \mathrm{H}$ NMR (acetone- $d_{6}, 400 \mathrm{MHz}$ ) and ${ }^{13} \mathrm{C}$ NMR (acetone- $d_{6}, 100 \mathrm{MHz}$ ) data, see Tables 3 and 4; HRESIMS $m / z 209.0811[\mathrm{M}-\mathrm{H}]^{-}$(calcd for $\mathrm{C}_{11} \mathrm{H}_{13} \mathrm{O}_{4}, 209.0814$ ).

Saturnispol H (8): light yellow oil. UV (MeOH) $(\log \varepsilon) \lambda_{\max } 219,347 \mathrm{~nm} ; \mathrm{IR}(\mathrm{MeOH}) v_{\max } 3438,2919$, 2850, 1736, 1653, 1381, 1367, $1229 \mathrm{~cm}^{-1} ;{ }^{1} \mathrm{H} \mathrm{NMR}\left(\mathrm{CD}_{3} \mathrm{OD}, 400 \mathrm{MHz}\right)$ and ${ }^{13} \mathrm{C}$ NMR $\left(\mathrm{CD}_{3} \mathrm{OD}, 100 \mathrm{MHz}\right)$ data, see Tables 3 and 4; HRESIMS $m / z$ 207.0657 [M - H] $]^{-}$(calcd for $\mathrm{C}_{11} \mathrm{H}_{11} \mathrm{O}_{4}$, 207.0657).

\subsection{ECD Calculation}

Conformational analyses were carried out via random searching in the Sybyl-X 2.0 using the MMFF94S force field with an energy cutoff of $2.5 \mathrm{kcal} / \mathrm{mol}$. Subsequently, the conformers were re-optimized using discrete fourier transform (DFT) at the B3LYP/6-31++G (d) level in the gas phase using the GAUSSIAN 09 program. The energies, oscillator strengths, and rotational strengths (velocity) of the first 60 electronic excitations were calculated using the time-dependent density functional theory (TDDFT) methodology at the B3LYP/6-311++G $(2 \mathrm{~d}, 2 \mathrm{p})$ level in vacuum. The ECD spectra were simulated by the overlapping Gaussian function (half the bandwidth at 1 /e peak height, $\sigma=0.2 \mathrm{eV}$ ). To obtain the final spectra, the simulated spectra of the conformers for each structure were averaged according to the Boltzmann distribution theory and their relative Gibbs free energy $(\Delta G)$. Theoretical ECD spectra of the corresponding enantiomers were obtained by the direct inversions of the ECD spectra of the abovementioned compounds.

\subsection{Antibacterial Assay}

All compounds were tested for antibacterial activities against Gram-positive bacteria, S. aureus (ATCC 29213), B. subtilis, and vancomycin-resistant E. faecalis A4; Gram-negative P. aeruginosa 14; and pathogenic bacterium K. pneumoniae. The minimum inhibitory concentrations (MIC) were determined using the broth micro-dilution method according to the clinical and laboratory standards institute (CLSI) 2015 guideline. The commercial antimicrobial agents Ciprofloxacin, Colistin, and Bacaucin were used as positive controls. After $16-20 \mathrm{~h}$ incubation at $37^{\circ} \mathrm{C}$, MIC values were defined as the lowest concentrations of antibiotics with no visible growth of bacteria. Values of more than $64 \mu \mathrm{g} / \mathrm{mL}$ were considered as no antibacterial activity.

\section{Conclusions}

Our work first explored the secondary metabolites of $T$. saturnisporum derived from a marine sponge, and continued to uncover eight new sorbicillin-based derivatives. This finding provided additional evidence to support the assumption that the same fungal species from a marine environment are capable of activating a distinct biosynthetic pathway, like those of terrestrial origin. Saturnispols A-H as the sorbicillin-based derivatives are classified into five different scaffolds, while a terminal hydroxylation at the side chain is rare in the sorbicillinold family. In the biogenetic consideration, these compounds were generated from sorbicillinol as a precursor to derive different skeletons. Compound $\mathbf{6}$ serves as a new natural scaffold that possesses significant inhibition against drug-resistant bacterium (VRE), suggesting it to be a potential lead to overcome certain drug-resistant pathogens after structural optimization. In addition, both K. pneumonia and P. aeruginosa are Gram-negative, indicating that they are resistant to a large range of antibiotics, resulting in clinically unsuccessful treatment. The significant inhibition of $\mathbf{6}$ against these two pathogens suggests that it may be a promising agent against Gram-negative bacteria. 
Supplementary Materials: The following are available online at http:/ /www.mdpi.com/1660-3397/16/7/226/s1, HRESIMS, ${ }^{1} \mathrm{H},{ }^{13} \mathrm{C}$ NMR, HSQC, HMBC, ROESY, and IR spectra of the new compounds.

Author Contributions: J.M. and H.H. isolated all compounds; W.C. and B.W. help to measure all spectra and ECD calculation; K.Z. tested the antibacterial effects; B.K. conducted the solid fermentation of the fungus; W.L. elucidated the structures of new compounds and edited the manuscript.

Funding: This research received no external funding.

Acknowledgments: This work was financially supported by the grants from the 973 program (2015CB755906), the National Natural Science Foundation of China (21672010, 81630089, 41376127, U1606403), and BMBF114S916 (TÜBİTAK).

Conflicts of Interest: The authors declare no conflict of interest.

\section{References}

1. Meng, J.; Wang, X.; Xu, D.; Fu, X.; Zhang, X.; Lai, D.; Zhou, L.; Zhang, G. Sorbicillinoids from fungi and their bioactivities. Molecules 2016, 21, e715. [CrossRef] [PubMed]

2. Harned, A.M.; Volp, K.A. The sorbicillinoid family of natural products: Isolation, biosynthesis and synthetic studies. Nat. Prod. Rep. 2011, 28, 1790-1810. [CrossRef] [PubMed]

3. Cram, D.J. Mold metabolism. II. The structure of sorbicillin, a pigment produced by the mold Penicillium notatum. J. Am. Chem. Soc. 1948, 70, 4240-4243. [CrossRef] [PubMed]

4. El-Elimat, T.; Raja, H.A.; Figueroa, M.; Swanson, S.M.; Falkinham, J.O., III; Lucas, D.M.; Grever, M.R.; Wani, M.C.; Pearce, C.J.; Oberlies, N.H. Sorbicillinoid analogs with cytotoxic and selective anti-Aspergillus activities from Scytalidium album. J. Antibiot. 2015, 68, 191-196. [CrossRef] [PubMed]

5. Abdel-Lateff, A.; Fisch, K.; Wright, A.D. Trichopyrone and other constituents from the marine sponge-derived fungus Trichoderma sp. Z. Naturforsch. 2009, 64c, 186-192. [CrossRef]

6. Zhai, M.; Qi, F.; Li, J.; Jiang, C.; Hou, Y.; Shi, Y.; Di, D.; Zhang, J.; Wu, Q. Isolation of secondary metabolites from the soil-derived fungus Clonostachys rosea YRS-06, a biological control agent, and evaluation of antibacterial activity. J. Agric. Food Chem. 2016, 64, 2298-2306. [CrossRef] [PubMed]

7. Koyama, N.; Ohshiro, T.; Tomoda, H.; Omura, S. Fungal isobisvertinol, a new inhibitor of lipid droplet accumulation in mouse macrophages. Org. Lett. 2007, 9, 425-428. [CrossRef] [PubMed]

8. Trifonov, L.S.; Hilpert, H.; Floersheim, P.; Dreiding, A.S.; Rast, D.M.; Skrivanova, R.; Hoesch, L. Bisvertinols: A new group of dimeric vertinoids from Verticillium intertextum. Tetrahedron 1986, 42, 3157-3179. [CrossRef]

9. Li, D.; Cai, S.; Zhu, T.; Wang, F.; Xiao, X.; Gu, Q. Three new sorbicillin trimers, trisorbicillinones B, C, and D, from a deep ocean sediment derived fungus, Phialocephala sp. FL30r. Tetrahedron 2010, 66, 5101-5106. [CrossRef]

10. Li, D.; Wang, F.; Xiao, X.; Fang, Y.; Zhu, T.; Gu, Q.; Zhu, W. Trisorbicillinone A, a novel sorbicillin trimer, from a deep sea fungus, Phialocephala sp. FL30r. Tetrahedron Lett. 2007, 48, 5235-5238. [CrossRef]

11. Cabrera, G.M.; Butler, M.; Rodriguez, A.; Godeas, A.; Haddad, R.; Eberlin, M.N. A sorbicillinoid urea from an intertidal Paecilomyces marquandii. J. Nat. Prod. 2006, 69, 1806-1808. [CrossRef] [PubMed]

12. Peng, J.; Zhang, X.; Du, L.; Wang, W.; Zhu, T.; Gu, Q.; Li, D. Sorbicatechols A and B, antiviral sorbicillinoids from the marine- derived fungus Penicillium chrysogenum PJX-17. J. Nat. Prod. 2014, 77, 424-428. [CrossRef] [PubMed]

13. Guo, W.; Peng, J.; Zhu, T.; Gu, Q.; Keyzers, R.A.; Li, D. Sorbicillamines A-E, nitrogen-containing sorbicillinoids from the deep-sea-derived fungus Penicillium sp. F23-2. J. Nat. Prod. 2013, 76, 2106-2112. [CrossRef] [PubMed]

14. Du, L.; Zhu, T.J.; Li, L.Y.; Cai, S.X.; Zhao, B.Y.; Gu, Q.Q. Cytotoxic sorbicillinoids and bisorbicillinoids from a marine-derived fungus Trichoderma sp. Chem. Pharm. Bull. 2009, 57, 220-223. [CrossRef] [PubMed]

15. Dunlop, R.W.; Simon, A.; Sivasithampara, K.; Ghisalberti, E.L. An antibiotic from Trichoderma Koningii active against soilborne plant pothogens. J. Nat. Prod. 1989, 52, 67-74. [CrossRef]

16. Bringmann, G.; Lang, G.; Gulder, T.A.M.; Tsuruta, H.; Mühlbacher, J.; Maksimenka, K.; Steffens, S.; Schaumann, K.; Stohr, R.; Wiese, J. The first sorbicillinoid alkaloids, the antileukemic sorbicillactones A and B, from a sponge-derived Penicillium chrysogenum strain. Tetrahedron 2005, 61, 7252-7265. [CrossRef]

17. Kawahara, T.; Takagi, M.; Shin-ya, K. JBIR-124: A novel antioxidative agent from a marine sponge-derived fungus Penicillium citrinum. J. Antibiot. 2012, 65, 45-47. [CrossRef] [PubMed]

18. Mazzucco, C.E.; Warr, G. Trichodimerol (BMS-182123) inhibits lipopolysaccharide-induced eicosanoid secretion in THP-1 human monocytic cells. J. Leukocyte Biol. 1996, 60, 271-277. [CrossRef] [PubMed] 
19. Bringmann, G.; Lang, G.; Bruhn, T.; Schäffler, K.; Steffens, S.; Schmaljohann, R.; Wiese, J.; Imhoff, J.F. Sorbifuranones A-C, sorbicillinoid metabolites from Penicillium strains isolated from Mediterranean sponges. Tetrahedron 2010, 66, 9894-9901. [CrossRef]

20. Sperry, S.; Samuels, G.J.; Crews, P. Vertinoid polyketides from the saltwater culture of the fungus Trichoderma longibrachiatum separated from a Haliclona marine sponge. J. Org. Chem. 1998, 63, 10011-10014. [CrossRef]

21. Ritieni, A.; Fogliano, V.; Nanno, D.; Randazzo, G.; Altomare, C.; Perrone, G.; Bottalico, A.; Maddau, L.; Marras, F. Paracelsin E, a new peptaibol from Trichoderma saturnisporum. J. Nat. Prod. 1995, 58, 1745-1748. [CrossRef] [PubMed]

22. Diánez, M.F.; Santos, M.; Carretero, F.; Marín, F. Trichoderma saturnisporum, a new biological control agent. J. Sci. Food Agric. 2016, 96, 1934-1944. [CrossRef] [PubMed]

23. Andrade, R.; Ayer, W.A.; Mebe, P.P. The metabolites of Trichoderma longibrachiatum. Part 1. Isolation of the metabolites and the structure of trichodimerol. Can. J. Chem. 1992, 70, 2526-2535. [CrossRef]

24. Harada, N.; Nakanishi, K. Circular Dichroic Spectroscopy Exciton Coupling in Organic Stereochemistry; University Science Books: Mill Valley, CA, USA, 1983.

25. Mazzeo, G.; Santoro, E.; Andolfi, A.; Cimmino, A.; Troselj, P.; Petrovic, A.G.; Superchi, S.; Evidente, A.; Berova, N. Absolute configurations of fungal and plant metabolites by chiroptical methods. ORD, ECD, and VCD studies on phyllostin, scytolide, and oxysporone. J. Nat. Prod. 2013, 76, 588-599. [CrossRef] [PubMed]

26. Ding, Y.; Li, X.; Ferreira, D. Theoretical calculation of electronic circular dichroism of the rotationally restricted 3,8-biflavonoid morelloflavone. J. Org. Chem. 2007, 72, 9010-9017. [CrossRef] [PubMed]

27. Abe, N.; Sugimoto, O.; Tanji, K.; Hirota, A. Identification of the quinol metabolite "sorbicillinol", a key intermediate postulated in bisorbicillinoid biosynthesis. J. Am. Chem. Soc. 2000, 122, 12606-12607. [CrossRef]

28. Trifonov, L.S.; Dreiding, A.S.; Hoesch, L.; Rast, D.M. Isolation of four hexaketides from Verticillium intertextum. Helv. Chim. Acta 1981, 64, 1843-1846. [CrossRef]

29. Tauchi, T.; Sakuma, H.; Ohno, T.; Mase, N.; Yoda, H.; Takabe, K. Lipase-catalyzed kinetic resolution of tetronic acid derivatives bearing a chiral quaternary carbon: Total synthesis of (S)-(-)-vertinolide. Tetrahedron Asymmetry 2006, 17, 2195-2198. [CrossRef]

30. Abe, N.; Arakawa, T.; Hirota, A. The biosynthesis of bisvertinolone: Evidence for oxosorbicillinol as a direct precursor. Chem. Commun. 2002, 3, 204-205. [CrossRef]

31. He, W.; Liu, M.; Li, X.; Zhang, X.; Abdel-Mageed, W.M.; Li, L.; Wang, W.; Zhang, J.; Han, J.; Dai, H.; et al. Fungal biotransformation of tanshinone results in [4+2] cycloaddition with sorbicillinol: Evidence for enzyme catalysis and increased antibacterial activity. Appl. Microbiol. Biotechnol. 2016, 100, 8349-8357. [CrossRef] [PubMed]

32. Sugaya, K.; Koshino, H.; Hongo, Y.; Yasunaga, K.; Onose, J.; Yoshikawa, K.; Abe, N. The biosynthesis of sorbicillinoids in Trichoderma sp. USF-2690: Prospect for the existence of a common precursor to sorbicillinol and 5-epihydroxyvertinolide, a new sorbicillinoid member. Tetrahedron Lett. 2008, 49, 654-657. [CrossRef]

33. Neumann, K.; Abdel-Lateff, A.; Wright, A.D.; Kehraus, S.; Krick, A.; Konig, G.M. Novel sorbicillin derivatives with an unprecedented carbon skeleton from the sponge-derived fungus Trichoderma species. Eur. J. Org. Chem. 2007, 207, 2268-2275. [CrossRef]

34. Abe, N.; Murata, T.; Hirota, A. Novel oxidized sorbicillin dimers with 1,1-diphenyl-2-picrylhydrazyl radical scavenging activity from a fungus. Biosci. Biotechnol. Biochem. 1998, 62, 2120-2126. [CrossRef] [PubMed]

35. Ciminiello, P.; Fattorusso, E.; Magno, S.; Mangoni, A.; Pansini, M. A novel conjugated ketosteroid from the marine sponge Dictyonella incisa. J. Nat. Prod. 1989, 52, 1331-1333. [CrossRef]

36. Patrizia, C.; Ernesto, F.; Silvana, M.; Alfonso, M.; Maurizio, P. Incisterols, a new class of highly degraded sterols from the marine sponge Dictyonella incisa. J. Am. Chem. Soc. 1990, 112, 3505-3509.

37. Ciminiello, P.; Fattorusso, E.; Magno, S.; Mangoni, A.; Ialenti, A.; Di Rosa, M. Furan fatty acid steryl esters from the marine sponge Dictyonella incisa which show inflammatory activity. Experientia 1991, 47, 739-743. [CrossRef]

38. Murray, B.E. Vancomycin-resistant enterococcal infections. N. Engl. J. Med. 2000, 342, 710-721. [CrossRef] [PubMed]

(C) 2018 by the authors. Licensee MDPI, Basel, Switzerland. This article is an open access article distributed under the terms and conditions of the Creative Commons Attribution (CC BY) license (http:// creativecommons.org/licenses/by/4.0/). 